\title{
Geochemistry of Mafic Dykes of Chittoor District, Andhra Pradesh, Southern India
}

\author{
D. B. SANKAR, Y. V. REDDY and K. S. SAI PRASAD \\ Department of Geology, Sri Venkateswara University, Tirupati - 517502, India \\ ksspsvu@gmail.com
}

Received 29 January 2014 / Accepted 20 February 2014

\begin{abstract}
Mafic dykes are a kind of minor intrusions, usually occur within granitic pluton in Chittoor district, Andhra Pradesh, India. The origin of these dykes and its implications to the formation of granitic plutons in Chittoor were studied. The analytical results suggest that these mafic dykes are alkali dolerite and derived from continental arc. The mafic dyke samples contain 5.61wt $\% \mathrm{MgO}$; exhibit negative $\mathrm{Ba}, \mathrm{Nb}, \mathrm{Sr}, \mathrm{Zr}$ and $\mathrm{Ti}$ anomalies and they are enriched in $\mathrm{Cs}, \mathrm{Rb}, \mathrm{U}, \mathrm{K}, \mathrm{Nd}$ and Sm. It suggests that the mafic dykes are subduction related and contaminated during their intrusion. It is concluded that mantle wedge melting during the subduction process and basaltic underplating had provided the necessary heat to cause partial melting of continental crust, and generation of voluminous felsic magma.
\end{abstract}

Keywords: Mafic dykes, Geochemistry, Petrogenesis, subalkaline and alkaline

\section{Introduction}

Mafic dykes and Dyke swarms, having different orientations, are conspicuous in all the protocontinents of Indian Shield viz. Aravalli-Bundelkhand Protocontinent, Dharwar Protocontinent, Bastar - Bhandra Protocontinent and Singhbum Protocontinent ${ }^{1,2}$. Further the mafic dykes are often parallel to major transpersonal shear zones, which clearly indicates the tectonic control on their genesis. Hence, injection of mafic dykes at intervals throughout the Proterozoic provides a window to monitor mantle evolution and /changing magmatic style $^{3,4}$. A number of geochemical studies were carried out, with emphasis on the nature of the deep crust and the origin of igneous rocks. According to Drury ${ }^{5}$ and Murthy et al., ${ }^{6}$ in the southern region near Tirupati the oldest NE-SW trending dykes are followed by NNE trending dykes and the NW trending dykes emplaced near Anantapur in the southwestern area were oldest which were followed by NE-SW trending dykes. The intrusive igneous rocks in Chittoor include sub-volcanic intrusions of granodiorite and granite, minor intrusions of monzonite, quartz monzonite, rhyodacite, rhyolite and Precambrian mafic dykes are also noticed. In spite of the above detailed studies, uncertainties regarding the formation of such large granitoid bodies in Chittoor district were still under question. It was believed that continuous and huge amount of heat was required for the extensive crustal 
melting and generation of voluminous felsic magma in Proterozoic. However, the source of heat to cause the partial melting of continental crust was unknown. Within some granite plutons, there are mafic dykes which are believed to be derived from mantle magmas. The present study was carried out to determine the origin of the mafic dykes with control on the partial melting event occurred during Proterozoic.

\section{Experimental}

Fifteen rock samples were collected from five mafic dykes (D1 to D5) in Chittoor district, Andhra Pradesh, India (Location: $12^{\circ} 37^{\prime}-14^{\circ} 8^{\prime}$ north latitudes and $78^{\circ} 3^{\prime}-79^{\circ} 55^{\prime}$ east longitudes). Samples collected did not display any evidence of oxidation or hydration in hand specimen. Chilled margins are defined on the basis of both grain size and chemical composition. Detailed petrographic studies were carried out followed by the chemical analysis.

Major oxides were obtained using the X-ray fluorescence (XRF) on fused glass pellets. Accuracies of the XRF analysis were estimated as $2 \%$ for major elements present in concentrations greater than $0.5 \mathrm{wt} \%$ and $5 \%$ for trace elements. Trace elements $\mathrm{Rb}, \mathrm{Th}, \mathrm{U}$, $\mathrm{Nb}, \mathrm{La}, \mathrm{Sr}, \mathrm{Ce}, \mathrm{Nd}, \mathrm{Zr}, \mathrm{Hf}, \mathrm{Sm}, \mathrm{Tb}, \mathrm{Y}$ and $\mathrm{Pb}$, including Rare Earth Elements (REE) were determined by a VG Elemental Plasma Quad 2 inductively coupled plasma-mass spectrometer (ICP-MS). The analysis yields accuracies better than 5\%. Elements were measured simultaneously and a complete analysis can be made in the space of about 2 minutes, making it an extremely rapid analytical method.

\section{Petrography}

Mafic dykes occurring as individual, clusters and swarms intruding into Precambrian litho units, that exposed in Chittoor district. These mafic dykes are strong, dark greenish black in colour and slightly decomposed. The wall rock is granite, which is also strong, massive, pinkish-grey, with medium grained in texture. The contact between the dyke and wall rock is sharp and with fine grained at the chilled margin. The dyke is basically composed of basaltic composition with ophitic texture, including plagioclase feldspar, clino-pyroxene olivine, epidote and interstitial glass. The phenocrysts of quartz, olivine and biotite are observed in some and some of the phenocryst showed alteration by epidote and chlorite.

\section{Results and Discussion}

\section{Major oxides}

Major element data are shown in (Table 1). Since the dykes in the Chittoor were intruded to a very shallow crust surface and very fine grained, they could be classified as sub-volcanic rocks. With reference to the TAS diagram ${ }^{7}$ for volcanic rocks (Figure 1), most of the samples in this study are classified as basalt and a few of them are trachy basalt, which usually be found on stable continental crust or some oceanic islands. The silica content of the samples is within $46.5 \%$ to $51.62 \%$, which fall in the range of basic rocks. The AFM diagram plotted at its apices - Alkalis $\left(\mathrm{Na}_{2} \mathrm{O}+\mathrm{K}_{2} \mathrm{O}\right)$, Fe oxides $\left(\mathrm{FeO}+\mathrm{Fe}_{2} \mathrm{O}_{3}\right)$ and $\mathrm{MgO}$. The diagram shows boundary between the calc-alkaline field and the tholeiitic field. Most of the rock samples in the falls in the field of calc-alkaline (Figure 2).

Irvine \& Baragar $^{8}$ developed the Bivariate plot of silicate against total alkalis which divides rocks into sub-alkaline and alkaline series (Figure 3). The samples of this study area were plot in the sub-alkaline field. The samples of this study are rich in silica $(46.6 \%$ to $51.6 \%)$ and the concentration of alkalis ranges from $3.6 \%$ to $6.1 \%$, which indicates the magma was initially rich in pyroxene and olivine than alkali one. As the magma evolved, it was gradually depleted of pyroxene and olivine, and plagioclase and K-feldspar (Alkali-rich minerals) are crystallized. 


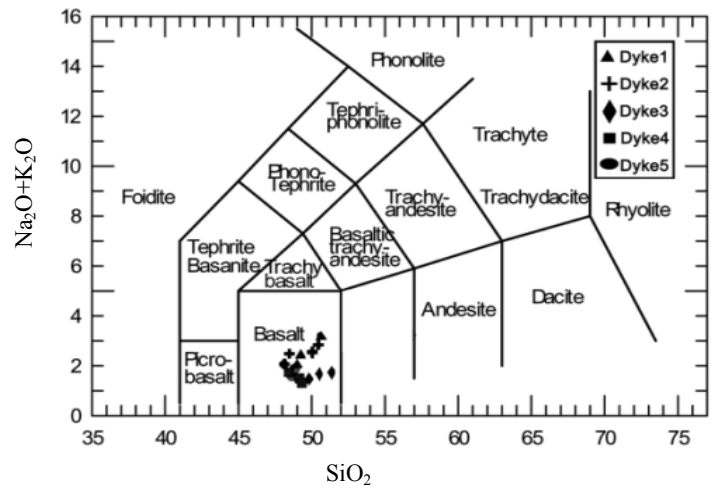

Figure 1. The chemical classification and nomenclature of volcanic rocks using the total alkalis versus silica (TAS) diagram of Le Bas et al., ${ }^{7}$.

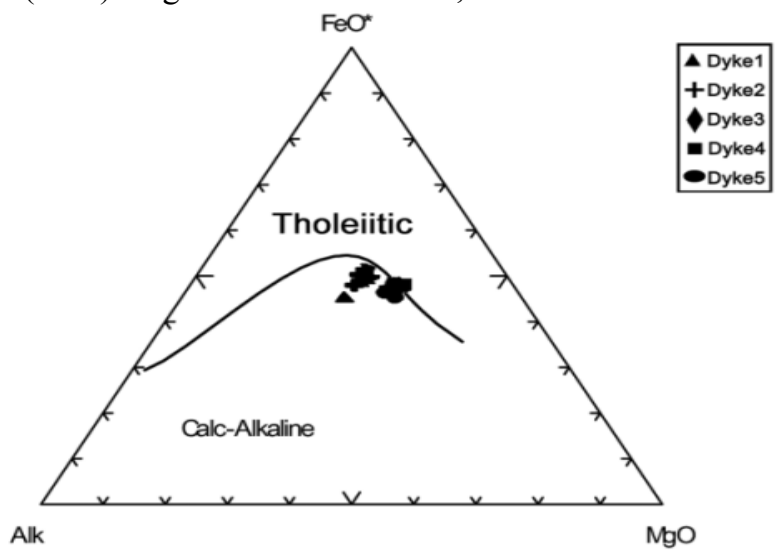

Figure 2. AFM Diagram ${ }^{8}$

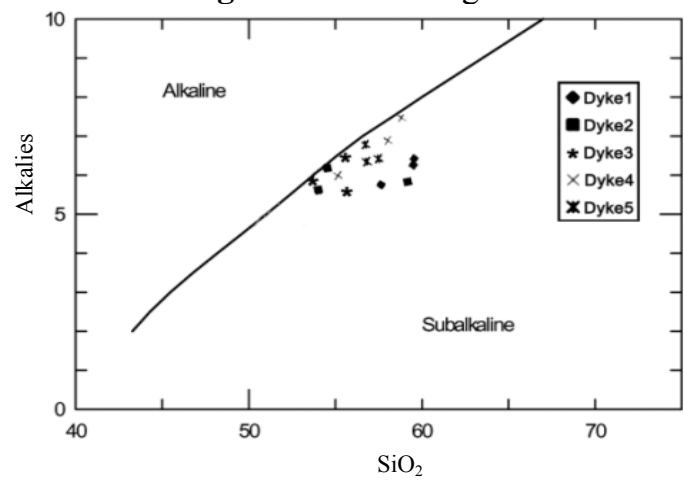

Figure 3. The Bivariate plot of silicate against total alkalies

A major element variation diagram against $\mathrm{MgO}$ shows that $\mathrm{Fe}_{2} \mathrm{O}_{3}, \mathrm{Na}_{2} \mathrm{O}, \mathrm{Al}_{2} \mathrm{O}_{3}, \mathrm{MnO}$ and $\mathrm{P}_{2} \mathrm{O}_{5}$ decrease while $\mathrm{TiO}_{2}$ increases, with increasing $\mathrm{MgO}$ (Figure 4). It indicates that these major oxides are formed in the earlier stage and were depleted as the magma continued to evolve. In particular, $\mathrm{SiO}_{2}, \mathrm{CaO}$ and $\mathrm{K}_{2} \mathrm{O}$ have no clear relationship with $\mathrm{Mg}$, suggest that crustal contamination is significant for these dykes. 

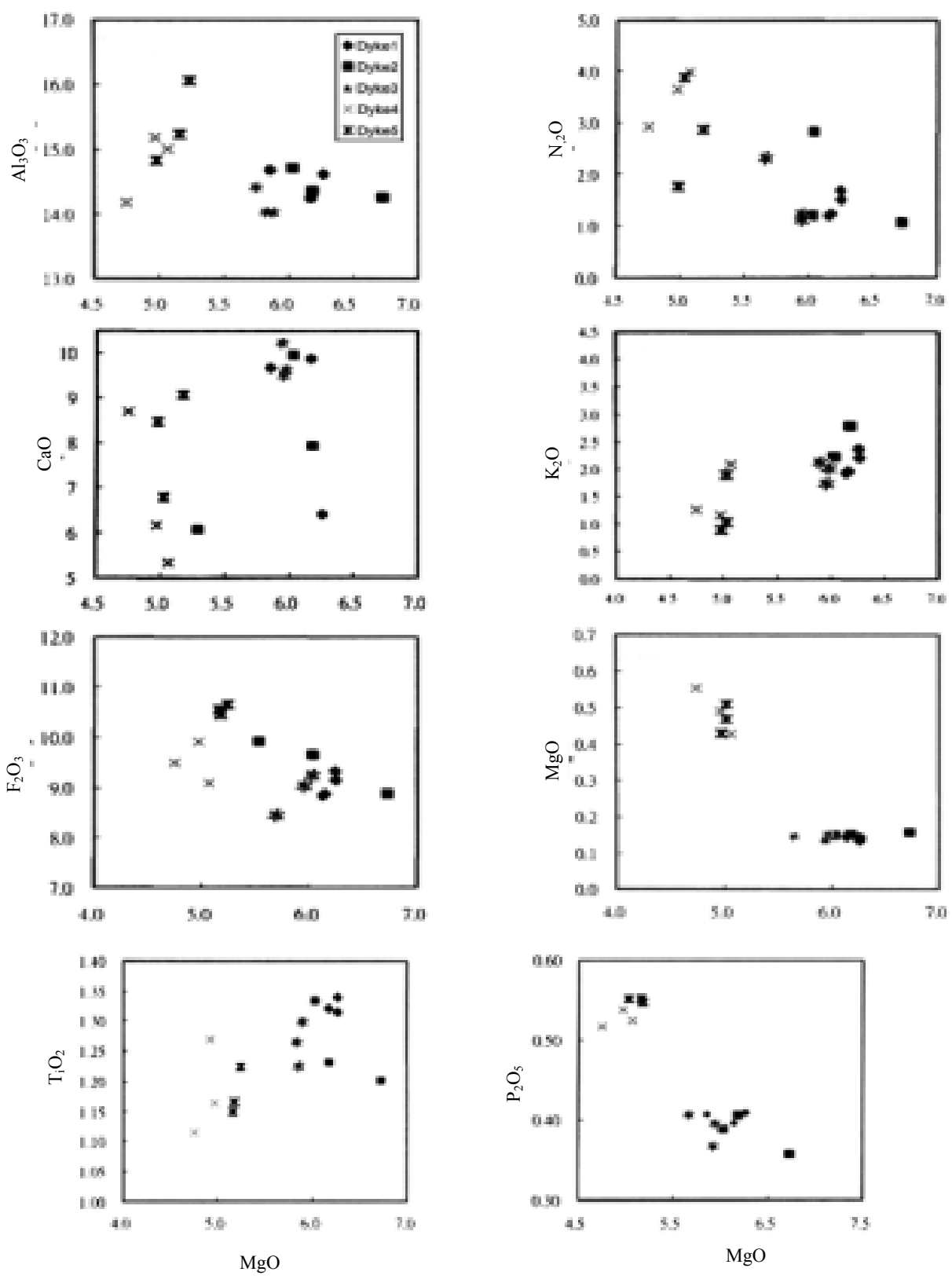

Figure 4. Harker variation diagram for mafic dykes of the study area

Trace elements and rare earth elements

The trace and REE concentrations are given in Table 1. Trace elemental data are normalized ${ }^{9}$ to the primitive mantle (Figure 5). These dykes exhibit negative anomalies of $\mathrm{Ba}, \mathrm{Nb}, \mathrm{Sr}, \mathrm{Zr}$ and $\mathrm{Ti}$, and they are enriched in $\mathrm{Cs}, \mathrm{Rb}, \mathrm{U}, \mathrm{K}, \mathrm{Nd}$ and $\mathrm{Sm}$.The result reflects the magma is contaminated by crust during its intrusion. Moreover, all samples show negative $\mathrm{Nb}$ and $\mathrm{Ta}$ anomalies and positive $\mathrm{Pb}$ anomalies, which are similar to island arc volcanics and continental crustal rocks. 


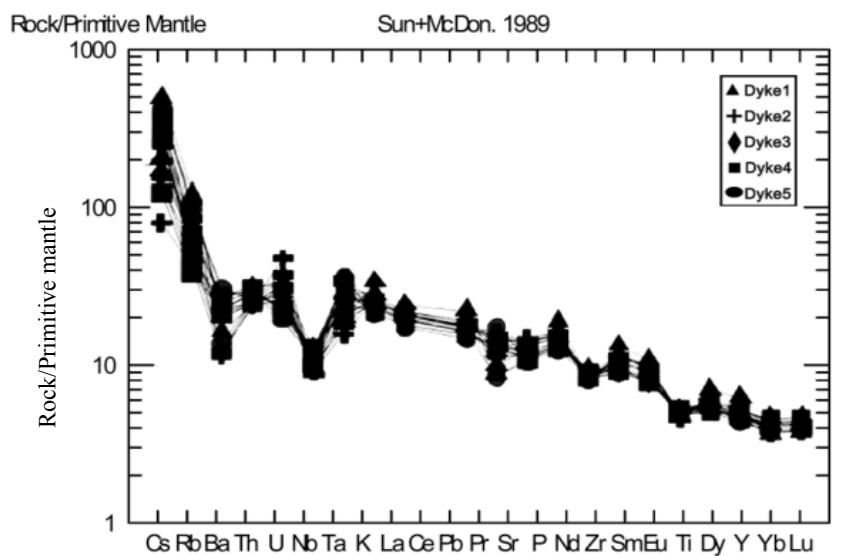

Figure 5. Primitive mantle normalized Trace elemental patterns (Normalization values are from Sun and Mc Donough ${ }^{9}$ ).

Chondrite-normalized REE pattern shows in Figure 6. The pattern is controlled by the REE chemistry of its source and the crystal-melt equilibria that have taken place during its evolution. The reasoning here is based upon the partition coefficients for the REE in the major rock-forming minerals. From the diagram, LREE enrichment and slight negative Eu anomalies. Feldspars (both plagioclase and potash feldspars), particularly in felsic magmas chiefly control europium anomalies. Therefore, the removal of feldspar from a felsic melt by crystal fractionation or the partial melting of a rock in which feldspar is retained in the source will give rise to a negative Eu anomaly in the melt. The extreme depletion of the HREE relative to the LREE may due to the large variation in the partition coefficients of the REE. The absence of a negative Ce anomaly indicates that these rocks are generally not affected by low-temperature alteration.

$\mathrm{The} \mathrm{Rb} / \mathrm{Sr}$ ratio of mantle segment is of 0.24 . The contaminated crust, on the other hand, which has differentiated from the mantle showing higher $\mathrm{Rb} / \mathrm{Sr}$ ratio upto 0.320 , and consequently radiogenic ${ }^{8} \mathrm{Sr}$ than the mantle ${ }^{10}$. A still higher value of 0.35 was calculated by Shaw et. al., ${ }^{11}$. The data for this study area indicates $(\mathrm{Rb} / \mathrm{Sr}$ ratio is 0.12 to 0.4$)$ that this dolerites are of assimilation product.

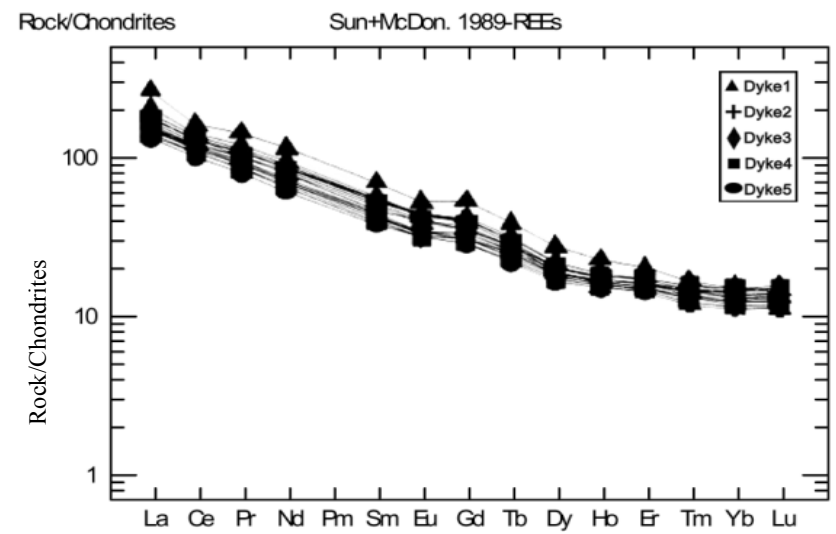

Figure 6. Primitive mantle normalized REE diagram (Normalization values are from Sun and Mc Donough ${ }^{9}$ ). 
Table 1. Major oxides (Wt $\%$ ) and Trace and REE (ppm) concentrations of mafic dykes

\begin{tabular}{|c|c|c|c|c|c|c|c|c|c|c|c|c|c|c|c|}
\hline \multirow{2}{*}{ 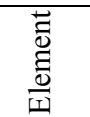 } & \multicolumn{3}{|c|}{ Dyke - 1} & \multicolumn{3}{|c|}{ Dyke - 2} & \multicolumn{3}{|c|}{ Dyke - 3} & \multicolumn{3}{|c|}{ Dyke - 4} & \multicolumn{3}{|c|}{ Dyke -5} \\
\hline & DBS1 & DBS2 & DBS3 & DBS4 & DBS5 & DBS6 & DBS7 & DBS8 & DBS9 & DBS10 & DBS11 & DBS12 & DBS13 & DBS14 & DBS15 \\
\hline $\mathrm{SiO}_{2}$ & 51.620 & 49.245 & 50.419 & 47.753 & 46.510 & 47.348 & 47.031 & 48.204 & 48.426 & 47.888 & 50.547 & 49.739 & 46.615 & 49.222 & 50.179 \\
\hline $\mathrm{TiO}_{2}$ & 1.340 & 1.321 & 1.314 & 1.201 & 1.231 & 1.334 & 1.369 & 1.289 & 1.235 & 1.114 & 1.205 & 1.232 & & 1.181 & 1.224 \\
\hline $\mathrm{Al}_{2} \mathrm{O}_{3}$ & 15.266 & 14.246 & 14.623 & 14.259 & 14.360 & 14.719 & 15.524 & 14.209 & 14.405 & 14.185 & 15.028 & 15.385 & 15.544 & 15.487 & 16.061 \\
\hline $\mathrm{Fe}_{2} \mathrm{O}_{3}$ & 9.267 & 9.377 & 9.030 & 8.873 & 9.234 & 9.653 & 8.524 & 9.247 & 8.834 & 9.497 & 9.090 & 11.496 & 10.457 & 11.753 & 10.655 \\
\hline $\mathrm{MnO}$ & 0.134 & 0.149 & 0.143 & 0.157 & 0.151 & 0.149 & 0.150 & 0.157 & 0.133 & 0.554 & 0.429 & & 0.501 & 0.575 & 0.501 \\
\hline $\mathrm{MgO}$ & 6.257 & 6.166 & 6.264 & 6.724 & 6.181 & & & 5.980 & & & & & & 5.289 & 5.236 \\
\hline $\mathrm{CaO}$ & 6.405 & 9.8641 .278 & & & & & & 9.676 & 10.243 & & & & & 17 & 5.193 \\
\hline $\mathrm{Na}_{2} \mathrm{O}$ & 264 & & & & & & & 37 & & & & & & 2.164 & 1.742 \\
\hline $\mathrm{K}_{2} \mathrm{O}$ & 2.375 & 1.965 & 2.21 & 2.906 & 2.791 & 2.226 & & 2.122 & & & & & & 394 & 3.185 \\
\hline $\mathrm{P}_{2} \mathrm{O}_{5}$ & 109 & 465 & & 0.357 & 0.406 & & & 0.397 & & & & & & 563 & 0.585 \\
\hline LOI & & 0 & & 65 & & & & 6.880 & & & & & & & 60 \\
\hline Total & & & .746 & .21 & & 99.145 & 99.317 & 99.198 & & & & & & 584 & \\
\hline \multicolumn{16}{|c|}{ Trace elements and REE } \\
\hline Cs & .086 & 13.427 & 5.726 & 23.283 & 16.390 & 25.546 & & 20.403 & & & & & & 5.745 & 5.733 \\
\hline $\mathrm{Ba}$ & 1.81 & 7.72 & 47.56 & 545.11 & 539.37 & 172.88 & 340 & & & & 319.53 & 28 & & 405.11 & 404.29 \\
\hline $\mathrm{Th}$ & 813 & 119 & 509 & 5.064 & 5.408 & 5.137 & & 66 & & & 4.664 & 4.873 & & 5.089 & 5.079 \\
\hline $\mathrm{U}$ & 785 & & 045 & 0.845 & 0.902 & 0.842 & & & & & & & & 331 & 2.327 \\
\hline $\mathrm{Nb}$ & 985 & & & 12.759 & 14.626 & 13.868 & & 14.965 & & & & .55 & & 11.04 & 11.02 \\
\hline $\mathrm{Rb}$ & 128.19 & 7.02 & 130.64 & $25 . .36$ & 217.25 & 250.75 & & 152.11 & & 91 & 352.93 & 67 & & 217.02 & 216.59 \\
\hline $\mathrm{Ta}$ & 1.119 & 922 & & 0.740 & 0.853 & 0.784 & & 10 & & 0.522 & 0.566 & & & 0.578 & 0.577 \\
\hline $\mathrm{La}$ & 36.622 & & & 30.645 & & 32.947 & & & & & & & & 45.481 & 45.389 \\
\hline $\mathrm{Ce}$ & & & & & & 64.671 & & & & 366 & & & & 98 & 85.824 \\
\hline $\operatorname{Pr}$ & & & & & & & & & & & & & & 80 & 58 \\
\hline $\mathrm{Nd}$ & 33.7 & & & & 32.222 & 31. & & & & & & & & 43.132 & 43.405 \\
\hline $\mathrm{Sm}$ & & & & & 6.304 & & & & & & & & & 8.873 & 8.855 \\
\hline $\mathrm{Eu}$ & 1.978 & 1.926 & 1.979 & 1.856 & 1.985 & 1.826 & 2.296 & 1.903 & 1.808 & 2.231 & 2.461 & 2.567 & 2.2525 & 2.620 & 2.614 \\
\hline Gd & 6.839 & 6.502 & 6.678 & 5.787 & 6.351 & 6.199 & 7.174 & 6.358 & 5.912 & 7.167 & 8.483 & 7.827 & 7.866 & & 8.475 \\
\hline $\mathrm{Tb}$ & & & & & & & & & & & & & & & \\
\hline Dy & 999 & 781 & 4.905 & 4.212 & 4.659 & 4.569 & & 4.679 & & & 45 & & & 5.670 & 5.659 \\
\hline Но & 987 & 0.938 & 0.998 & 0.844 & 0.942 & 0.910 & & 0.933 & & & 1.030 & & & 1.051 & 1.049 \\
\hline $\mathrm{Er}$ & 858 & 662 & 2.809 & 2.408 & 2.66 & & & 2.624 & & & & & & 2.838 & 2.832 \\
\hline $\mathrm{Tm}$ & 399 & 0.370 & & & 0.376 & & & & & & & & & & 0.385 \\
\hline $\mathrm{Yb}$ & 574 & & & 2.104 & & & & & & & & & & & 2.359 \\
\hline $\mathrm{Lu}$ & 0.388 & 0.358 & 0.380 & 0.317 & 0.358 & 0.345 & 0.377 & 0.360 & 0.334 & 0.286 & 0.338 & 0.300 & 0.318 & 0.350 & 0.349 \\
\hline
\end{tabular}




\section{Partial melting and crustal fractionation}

The trace element and ratios should vary considerably throughout the formation of rock, the enrichment in incompatiable and depleation in compatiably elements increasing uniformly with smaller degree of melting or more advanced crystal fractionation. The most highly incompatiable elements such as $\mathrm{Rb}, \mathrm{Nb}$, $\mathrm{Ta}$ and $\mathrm{Th}$ should increase more rapidly than $\mathrm{Sr}$ and $\mathrm{REE}^{12}$. At depths of less than $40 \mathrm{~km}$, plagioclase can be stable phase and will exert significant control on trace element patterns, because its distribution coefficients for REE, $\mathrm{Sr} / \mathrm{Ba}$ differ markedly from those of other common igneous minerals. The depletion of $\mathrm{Sr} / \mathrm{Ba}$ and negative Eu anomaly together with enrichment of incompatiable elements reflects the dominants of plagioclase in the late stages of differentiation ${ }^{13}$.

\section{Contamination and mixing}

The contamination, in the more common usage of the world, means built assimilation of crustal rocks by a mantle magma and this should be amenable to the mixing model. Trace elements are generally prepared for this purpose, since they frequently show a greater range of variation than major elements. The trace elements are mostly affected and becoming enriched in the altered igneous rocks, which are most mobile during weathering and show become relatively enriched (i e. $\mathrm{Na}, \mathrm{K}, \mathrm{Rb}, \mathrm{Cs}, \mathrm{Sr}, \mathrm{Ba}$ and $\mathrm{P}$ ). On the other hand $\mathrm{Ti}, \mathrm{Zr}, \mathrm{Nb}$, $\mathrm{Y}$ and HREE are extremely resistant to alteration (and/are relatively depleted) in metamorphosed basalts ${ }^{14,15}$.

\section{Petrogenesis}

The AFM diagram, Indicates that most of the rock samples in the study are calc-alkaline. Calcalkaline rock is given to suite of rocks comprising the plutonic association of gabbro- dioritegranodiorite - granite. They are typically developed on the continental side of plate subduction zones. The mafic dyke rocks in this study have relatively low $\mathrm{TiO}_{2}$ and $\mathrm{Nb} / \mathrm{La} \sim 0.40$ which are similar to the rocks that associated with the seduction process ${ }^{15}$. The dykes were also enriched in elements $\mathrm{Cs}, \mathrm{Rb}, \mathrm{U}, \mathrm{K}, \mathrm{Nd}, \mathrm{Sm}$, which are commonly enriched in subduction related rocks ${ }^{16}$. It suggests that mantle sources previously modified by subduction processes. The plotting of magnesium oxide against major oxides and trace elements, it is suggested that the magma sources of intrusion were different and result in the difference of geochemical composition. Another possible reason that contributes to the difference is that the dykes were from the same magma chamber but intruded in different time period. It is accepted that the mafic dykes were derived from mantle magma. Contamination of asthenospheric melts occurs during their ascent through the lithosphere. This contribute to a marked increase of $\mathrm{Cs}, \mathrm{Rb}, \mathrm{U}, \mathrm{K}, \mathrm{Nd}, \mathrm{Sm}$ and LREE; little change in $\mathrm{Ba}, \mathrm{Nb}, \mathrm{Sr}, \mathrm{Zr}$, Ti and HREE concentrations. Thus, negative anomalies of $\mathrm{Ba}, \mathrm{Nb}, \mathrm{Sr}, \mathrm{Zr}$, Ti and $\mathrm{Rb} / \mathrm{Sr}$ are resulted. It can be explained by the fact that the mafic magma was contaminated by the granitic country rock.

\section{Conclusion}

Most of the dyke rock in the study area is calc-alkaline dolerites in nature. The mafic dyke rocks have relatively low $\mathrm{TiO}_{2}$ and $\mathrm{Nb} / \mathrm{La} \sim 0.40$ which are similar to the rocks that associated with the subduction process. The mafic dykes were enriched in elements $\mathrm{Cs}, \mathrm{Rb}$, $\mathrm{U}, \mathrm{K}, \mathrm{Nd}, \mathrm{Sm}$, which resembles the subduction related rocks. Thus it is suggested that the magma sources of intrusion were different and result in the difference of geochemical composition or intruded in different time period. A marked increase of Cs, Rb, U, K, Nd, Sm and LREE; little change in $\mathrm{Ba}, \mathrm{Nb}, \mathrm{Sr}, \mathrm{Zr}, \mathrm{Ti}, \mathrm{Rb} / \mathrm{Sr}$ and HREE concentrations suggests the mafic magma was contaminated by the granitic country rock. 


\section{References}

1. Naqui S M, Geology and evolution of the Indian plate. Capital Publishing Company, New Delhi, India, 2005, 450.

2. Srivastava R K, Sivaji $\mathrm{C} H$ and Chalapathi Rao N V, (Eds.), Indian Dykes: Geochemistry, Geophysics and Geochronology. Narosa Publishing House Pvt. Ltd., New Delhi, 2008, 626.

3. Tarney J, Geochemistry and significance of mafic dyke swarms in the Proterozoic. In: Condie K C, (Ed.), Proterozoic Crustal Evolution. Elaevier, Amsterdam, 1992, 151-179.

4. Hall R P and Hugges D J, J Geological Society of London. 1993, 150, 625- 635.

5. $\quad$ Drury S A, J Geol Soc India, 1984, 25(7), 437-444.

6. Murthy Y G K, Babu Rao D, Guptasarma, Rao J M, Rao M.N and Bhattacharji S, Tectonic, Petrochemical and geophysical studies of mafic dyke swarms around the Proterozoic Cuddapah Basin., South India, In: Mafic dyke swarms (Ed., Halls H C, and Fahrig W F), Geol Ass Canada, 1987, 34. Spl. Paper, 303-316.

7. Lebas M J, Lemaitre R W, Streckeisen A and Zanettin B, J Petrology, 1986, 27(3), 745-750.

8. Irvine T N and Baragar W R A, J Geol Soc Canada, 1971, 8, 131-148.

9. Sun S S, McDonough W F, Special Publication, Geological Society, 1989, 42, 313-345.

10. Taylor S R, Geochim Cosmochim Acta, 1964, 28, 1273-1285.

11. Shaw D M, Reilly G A, Muysson J R, Pattenden G E and Campbell F E, Can J Earth Sci., 1967, 4, 829-853.

12. Staudigel H and Hart S R, Geochim Cosmochim Acta, 1983, 47, 337-350.

13. Zielinski R A, Geochim Cosmochim Acta, 1975, 39, 713-734.

14. Pearce J A and Cann J R, Earth Plan Sci Lett., 1973, 19, 290-300.

15. Winchester J A and Floyd P A, Earth Plan Sci Lett., 1976, 28, 459-469.

16. Hart S R and Brooks C J, Contr Mineral Petrol., 1977, 61, 109-128. 